\title{
Clinical and Radiographic Outcomes of Calcium Hydroxide vs Other Agents in Indirect Pulp Capping of Primary Teeth: A Systematic Review
}

\author{
Manisha Nair ${ }^{1}$, Deepa Gurunathan ${ }^{2}$
}

\begin{abstract}
Aim: To extract and systematically identify the existing literature on the "Clinical and radiographic outcome of calcium hydroxide vs other agents in indirect pulp capping of primary teeth".

Objective: To compare the clinical and radiographic outcome of calcium hydroxide and other agents in indirect pulp capping of primary teeth. Search strategy: The following databases were searched: PubMed Central, Cochrane Database of Systematic Reviews, Lilacs, Science Direct, Sigle. Bibliographies of clinical studies identified in the electronic search were analyzed for studies published outside the electronically searched journals. Selection criteria: Studies comparing the clinical and radiographic success rate of one or more indirect pulp capping agents with calcium hydroxide in primary molars were included.

Results: The initial search revealed 243 of which only 9 met the inclusion criteria and 234 were excluded based on the exclusion criteria. All the 9 included studies analysed the clinical and radiographic outcome of calcium hydroxide in comparison with other agents in indirect pulp capping of primary teeth.

Conclusion: There is a very limited good quality studies estimating the clinical and radiographic outcome of calcium hydroxide in comparison with other agents in indirect pulp capping of primary teeth. The review identified the need for more studies on the clinical and radiographic outcome of calcium hydroxide in comparison with other agents in indirect pulp capping of primary teeth.

Keywords: Biodentine, Calcium hydroxide, Indirect pulp capping, Mineral trioxide aggregate, Primary teeth.

International Journal of Clinical Pediatric Dentistry (2019): 10.5005/jp-journals-10005-1672
\end{abstract}

\section{INTRODUCTION}

Premature loss of deciduous tooth can lead to malocclusion, disintegration of dental arches, loss of function, and loss of esthetics. Hence, maintaining its vitality until its natural period of exfoliation is imperative for maintaining the arch form and integrity. To retain the tooth in the dental arch, either of the two treatments can be done, i.e., vital pulp therapy (VPT) or root canal treatment $(R C T)$.

Endodontic treatment of a child is a challenging clinical practice, as it involves administration of local anesthesia with the syringe. Managing a child in a dental set up which involves needle is a major thought-provoking task. Hence, VPT can be done in primary teeth which do not involve the administration of local anesthesia.

Vital pulp therapy involves three approaches (a) direct pulp capping, (b) indirect pulp capping and (c) pulpotomy. This systematic review intends to provide data on radiographic outcome of calcium hydroxide and various other agents in indirect pulp capping of deciduous teeth.

Indirect pulp capping is commended for teeth with deep caries approximating the pulp with no signs and symptoms of pulp deterioration. In this treatment, the deepest layer of the remaining carious dentine (affected dentin) is covered with biocompatible material. ${ }^{1}$ followed by an airtight restoration to achieve a good seal against microleakage, without the need to reencounter for the removal of remaining caries. ${ }^{2-4}$

Indirect pulp capping is defined as a procedure in which a protective liner or cement or dressing is placed over the remaining dentin after the removal of soft caries or infected dentin. ${ }^{5}$ Indirect pulp therapy intends to preserve the vitality of the deciduous
${ }^{1,2}$ Department of Pedodontics and Preventive Dentistry, Saveetha Dental College, Saveetha Institute of Medical and Technical Sciences (SIMATS), Chennai, Tamil Nadu, India

Corresponding Author: Manisha Nair, Department of Pedodontics and Preventive Dentistry, Saveetha Dental College, Saveetha Institute of Medical and Technical Sciences (SIMATS), Chennai, Tamil Nadu, India, Phone: +91 7358475739, e-mail: drmanishanair@gmail.com

How to cite this article: Nair M, Gurunathan D. Clinical and Radiographic Outcomes of Calcium Hydroxide vs Other Agents in Indirect Pulp Capping of Primary Teeth: A Systematic Review. Int J Clin Pediatr Dent 2019;12(5):437-444.

Source of support: Nil

Conflict of interest: None

tooth to avoid pulpectomy. Calcium hydroxide was acquainted to dentistry in 1921 by Hermann and has been considered the gold standard material used for indirect pulp capping. ${ }^{6}$ There are various renowned advantages to calcium hydroxide that have caused it to obtain this recognition. There are no independent clinical parameters to govern how much carious dentin should be removed during indirect pulp therapy. However, several microbiological studies have advocated excavation of only the superficial dentin layer during indirect pulp therapy. ${ }^{7-9}$ This soft, yellow, humid, and necrotic layer is called the infected dentin, and it cannot be remineralized.

The ideology is that the dental pulp holds the ability to form the dentin-like matrix called the reparative dentin or 
tertiary dentin. Formation of reparative dentin occurs through cellular differentiation, extracellular matrix deposition, and mineralization. ${ }^{10,11}$ Several shortcomings of calcium hydroxide like disintegration and formation of tunnel defects ${ }^{12}$ have led to use of other agents in indirect pulp capping for deciduous teeth.

An ideal pulp capping agent should have properties like ability to form reparative dentin, to maintain the pulp vitality, to eliminate the bacteria, to be sterile and radiopaque, and to provide good bacterial seal. ${ }^{13}$

Other agents like calcium phosphate cement, polycarboxylate cement, RM-GIC, bonding agents, and lasers, have been familiarized for indirect pulp capping.

Recent advances in indirect pulp capping of deciduous teeth include mineral trioxide aggregate (MTA) and biodentine. MTA was brought into limelight by Torabinejad in the early 1900s. Various studies reported that MTA induced less pulpal irritation and more anticipated hard tissue barrier formation in comparison with hard setting calcium hydroxide. ${ }^{14}$

Biodentine is new-fangled bioactive cement with dentin-like mechanical properties. It can be used as a substitute for dentin. It has a progressive effect on vital pulp cells and stimulates tertiary dentin formation. ${ }^{15}$

This systematic review intends to provide information on the clinical and radiographic outcome of calcium hydroxide as an indirect pulp capping agent in deciduous teeth in comparison with other agents.

\section{Materials and Methods}

\section{Aim}

To extract and systematically identify the existing literature on the "Clinical and Radiographic outcome of Calcium Hydroxide vs Other Agents in Indirect Pulp Capping of Primary Teeth".

\section{Structured Question}

What is the ideal indirect pulp capping agent for primary teeth?

\section{PICO}

Population: Deciduous teeth, children.

Intervention: Indirect pulp treatment, MTA, biodentine, dentin bonding agent, calcium phosphate cement, hydroxyapatite, laser, Mtya1-Ca, bone morphogenic protein, bone sialoprotein, novel endodontic cement, emdogain gel, odontogenic ameloblast-associated protein, endo sequence root repair material, theracal, zinc oxide eugenol, corticosteroids, antibiotics, polycarboxylate cement, glass ionomer, and resinmodified glass ionomer.

Comparison: Calcium hydroxide.

Outcome: Clinical outcome, radiographic outcome, dentin bridge formation.

\section{Search Methods for Identification of Studies}

To include all the studies for this review, detailed search strategies were developed for each database. The following computer databases were used to retrieve articles for the review

- PubMed (up to November 2017)

- Cochrane Library (up to November 2017)

- Science Direct (up to November 2017)

- LILACS (up to November 2017)

- SIGLE (up to November 2017) (Flowchart 1).

\section{Search Strategy}

Search 1-PubMed (MeSHterms) and (keywords):

Search pediatric dentistry OR kids OR children OR deciduous teeth OR deciduous molars OR primary teeth OR primary molars OR milk teeth OR baby teeth OR deep caries OR decayed teeth OR dental caries OR carious teeth AND indirect pulp capping OR indirect pulp therapy OR vital pulp therapy OR indirect pulp treatment OR mineral trioxide aggregate OR MTA OR portland cement OR MTA Plus OR MTA Flow OR ProRoot MTA OR gray MTA OR white MTA OR angelus MTA OR medicept MTA OR endocem MTA OR biodentin OR biodentine OR septodont biodentine OR tricalcium silicate OR dentin bonding agent OR 4-META-MMA-TBB adhesive OR Bond It OR hybridizing dentin bonding agent OR adhesive resin OR scotchbond OR calcium phosphate cement OR tetracalcium phosphate OR hydroxyapatite OR CPNE7 protein OR novel endodontic cement OR NEC OR CEM cement OR theracal OR theracal LC OR zinc oxide eugenol OR corticosteroids OR antibiotics OR polycarboxylate cement OR durelon OR glass ionomer cement OR GIC OR resin-modified glass ionomer cement OR RMGIC OR vitremer OR fuji AND calcium hydroxide OR dycal OR vitrabond AND clinical success OR radiographic success OR dentin bridge formation OR dentin thickness OR radiographic dentin thickness OR reactionary dentin.

\section{Inclusion and Exclusion Criteria}

Studies were selected based on the following inclusion criteria:

- All the studies including indirect pulp treatment in primary molars using calcium hydroxide in comparison with other agents

- Studies comparing clinical success and radiographic reparative dentin thickness and/or radiographic outcome between calcium hydroxide and other agents in indirect pulp treatment for primary teeth.

Studies were debarred based on the following exclusion criteria (Table 1):

- Studies involving permanent teeth

- Studies involving direct pulp capping cases

- Studies evaluating parameters other than radiographic outcome.

\section{Results (Table 2, Figs 1 and 2) Study Selection}

The systematic search from PubMed, Cochrane library, ScienceDirect, LILACS, and SIGLE, and through hand-search revealed a total of 281 citations. On title screening, 257 articles were eliminated. After abstract screening and reviewing of full articles, 10 were included for the systematic review. A total of 10 articles met the inclusion criteria and were selected for the area of intended research.

\section{Study Characteristics (Table 3)}

Falster et al. stated that the 2-year outcome of primary molars subjected to indirect pulp treatment and restored with a composite resin was similar when the protection of the dentinpulp complex was performed with a layer of calcium hydroxide or only with an adhesive resin system. The most frequent cause for failure of the indirect pulp treatment in this study was the development of interradicular and/or periapical lesions that indicated the presence of irreversible pulp inflammation or necrosis. In this prospective and randomized clinical trial, the 
Flowchart 1: PRISMA flowchart

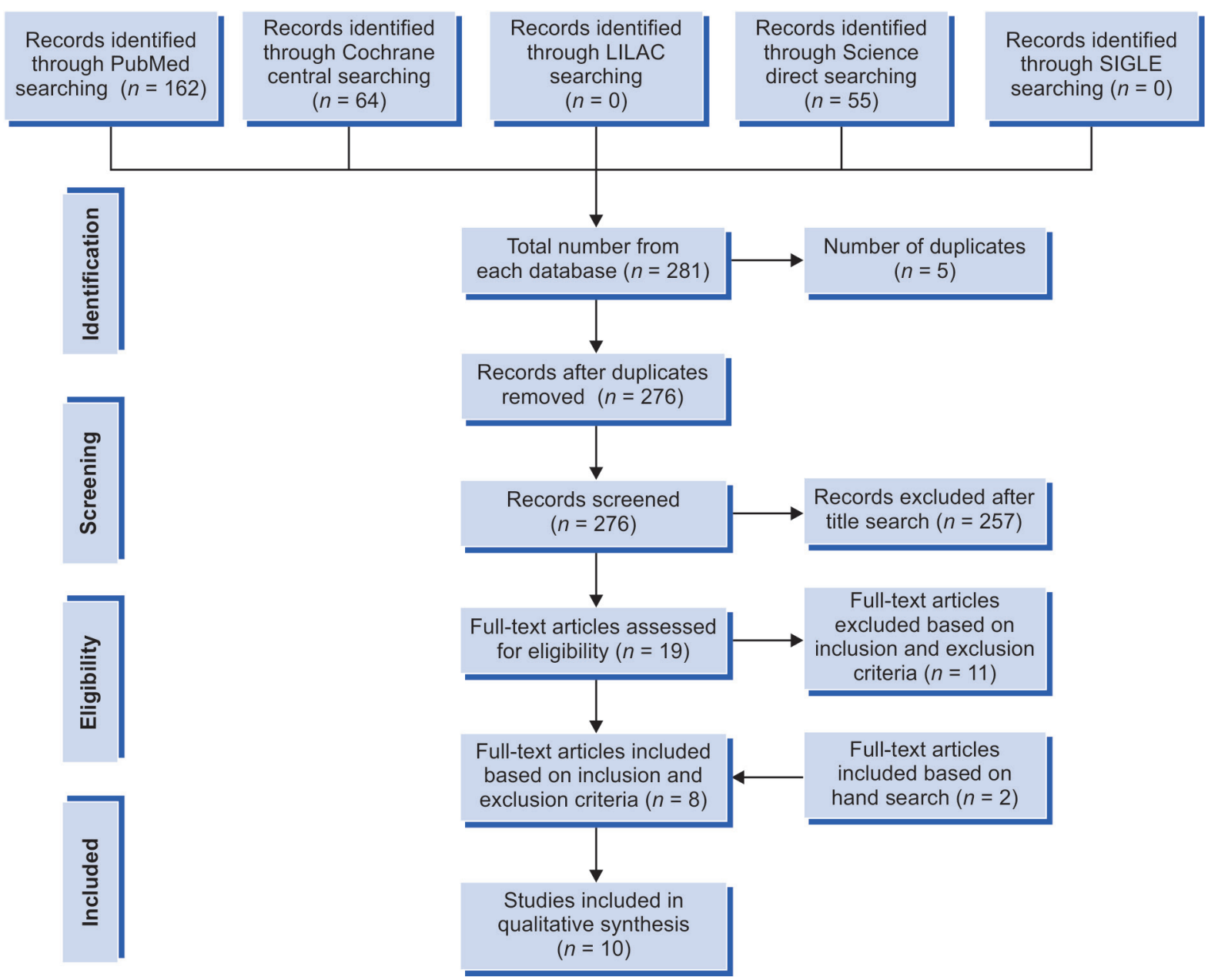

Table 1: Characteristics of excluded articles

\begin{tabular}{|c|c|}
\hline Author and year & Reason for exclusion \\
\hline Dhar et al. 2017 & Review article \\
\hline Pereira et al. 2017 & $\begin{array}{l}\text { Outcome measures were color, } \\
\text { consistency, and moisture of dentin and } \\
\text { bacterial count of the carious lesion }\end{array}$ \\
\hline Elshamy et al. 2016 & In vitro study \\
\hline Soares et al. 2016 & Permanent teeth were involved \\
\hline Dalpian et al. 2014 & No comparison group \\
\hline Petrou et al. 2014 & Permanent teeth were involved \\
\hline Fernandes et al. 2013 & Review article \\
\hline Maltz et al. 2013 & Permanent teeth were involved \\
\hline Sinha et al. 2011 & Permanent teeth were involved \\
\hline Maltz et al. 2011 & Permanent teeth were involved \\
\hline Wegehaupt et al. 2009 & $\begin{array}{l}\text { Outcome measures were remaining } \\
\text { dentin thickness and depth of the cavity }\end{array}$ \\
\hline Costa et al. 2003 & Permanent teeth were involved \\
\hline Al-Zayer et al. 2003 & Retrospective study \\
\hline Do Nascimento et al. 2000 & Permanent teeth were involved \\
\hline De Souza Costa et al. 2001 & Permanent teeth were involved \\
\hline Hebling et al. 1999 & Permanent teeth were involved \\
\hline
\end{tabular}

overall success rate of indirect pulp treatment was approximately $90 \%$ after 2 years.

Marchi et al. concluded that the clinical and radiographic success of a 48-month follow-up of the indirect pulp capping was similar when the protection of the dentin-pulp complex was performed with glass ionomer cement (93\%) or with a layer of calcium hydroxide (89\%) with no statistical significant difference between the materials. The most frequent cause of failures in both groups was the clinical observation of a fistula in the period of a 6-12-month follow-up, suggesting a misdiagnosis of the pulpal condition.

Casagrande et al. concluded that indirect pulp treatment has a high clinical and radiographic long-term success rate in primary teeth and provides a conservative, alternative treatment of teeth with deep carious lesions.

Casagrande et al. stated that IPT has a high clinical and radiographic success rate in primary teeth, independent of capping materials used over the remaining carious dentin. IPT provides a conservative alternative treatment of primary teeth with deep caries.

Buyukgural et al. evaluated 240 primary teeth and concluded that after 2 years, the clinical and radiographic success rates were $100 \%$. With regard to protection of dentin-pulp complex, all the four groups showed similar outcomes. 
Table 2: Quality of assessment of the included studies

\begin{tabular}{|c|c|c|c|c|c|c|c|c|c|}
\hline S. no. & Study & $\begin{array}{l}\text { Random } \\
\text { sequence } \\
\text { generation }\end{array}$ & $\begin{array}{l}\text { Allocation } \\
\text { concealment }\end{array}$ & $\begin{array}{l}\text { Blinding of } \\
\text { participants } \\
\text { and personnel }\end{array}$ & $\begin{array}{l}\text { Blinding of } \\
\text { outcome } \\
\text { assessment }\end{array}$ & $\begin{array}{l}\text { Incomplete } \\
\text { outcome data } \\
\text { assessment }\end{array}$ & $\begin{array}{l}\text { Selective } \\
\text { reporting of } \\
\text { outcome }\end{array}$ & $\begin{array}{l}\text { Other source } \\
\text { of bias }\end{array}$ & Risk of bias \\
\hline 1 & $\begin{array}{l}\text { Falster et al. } \\
2002\end{array}$ & High risk & Unclear risk & Unclear risk & Unclear risk & Low risk & Unclear risk & Low risk & High risk \\
\hline 2 & $\begin{array}{l}\text { Marchi et al. } \\
2006\end{array}$ & High risk & Unclear risk & Unclear risk & Unclear risk & Low risk & Unclear risk & Unclear risk & High risk \\
\hline 3 & $\begin{array}{l}\text { Casagrande } \\
\text { et al. } 2008\end{array}$ & High risk & Unclear risk & Unclear risk & Unclear risk & Low risk & Unclear risk & Unclear risk & High risk \\
\hline 4 & $\begin{array}{l}\text { Casagrande } \\
\text { et al. } 2008\end{array}$ & High risk & Unclear risk & Unclear risk & Low risk & Low risk & Unclear risk & Unclear risk & High risk \\
\hline 5 & $\begin{array}{l}\text { Buyukgural } \\
\text { et al. } 2008\end{array}$ & Low risk & Low risk & Low risk & Unclear risk & Low risk & Unclear risk & Unclear risk & High risk \\
\hline 6 & $\begin{array}{l}\text { Casagrande } \\
\text { et al. } 2010\end{array}$ & High risk & Unclear risk & Unclear risk & Unclear risk & Low risk & Unclear risk & Unclear risk & High risk \\
\hline 7 & $\begin{array}{l}\text { Chutima et al. } \\
2013\end{array}$ & High risk & Unclear risk & Unclear risk & Low risk & Low risk & Unclear risk & Unclear risk & High risk \\
\hline 8 & $\begin{array}{l}\text { Mathur et al. } \\
2016\end{array}$ & Low risk & High risk & High risk & High risk & Low risk & Unclear risk & Unclear risk & High risk \\
\hline 9 & $\begin{array}{l}\text { Rangel et al. } \\
2017\end{array}$ & Low risk & Low risk & Low risk & Low risk & Low risk & Unclear risk & Low risk & Moderate risk \\
\hline 10 & $\begin{array}{l}\text { George et al. } \\
2017\end{array}$ & Unclear risk & High risk & High risk & High risk & Low risk & Unclear risk & High risk & High risk \\
\hline
\end{tabular}

Casagrande et al. evaluated 32 teeth from a total baseline of 40. 25 cases met the criteria for clinical and radiographic success, reaching an overall success rate of $78 \%$ with no statistical difference between the groups. Failures occurred after the first-year follow-up and were detected by radiographic evaluation.

Chutima et al. stated that there was no statistically significant difference in overall success rates between calcium hydroxide indirect pulp treatment (CH-IPT) and 3Mix-MP sterilization (3MixMP) for the management of deep caries approximating the pulp in mandibular primary molars at either the 6-11-month or the 12-29-months follow-ups.

In Mathur et al., all the three dental materials tested, i.e., calcium hydroxide (setting), GIC type VII, and MTA, were found to be equally suitable for IPT, following clinical and radiographic criteria. The success rate with calcium hydroxide (setting) was found to be 93.5\%; with GIC (type VII), it was $97 \%$, and with MTA, it was $100 \%$, respectively.

Rangel et al. included 80 children, aged four to eight years old, with 160 primary teeth that were treated in a split-mouth design trial comparing indirect pulp capping using bioactive tricalcium silicate or calcium hydroxide. The teeth were restored with preformed crowns and assessed clinically and radiographically for one, three, six, and 12 months. The combined clinical and radiographic success rates were $98.3 \%$ for tricalcium silicate and $95 \%$ for calcium hydroxide. No significant differences were found for success rates between the two study groups $(p>0.05)$. The combined success rates for both groups were $96.7 \%$.

In George et al., clinically both MTA and dycal are good IPT medicaments in primary teeth. Radiographically, MTA is superior to dycal as IPT medicament in primary teeth. Dentin deposition is more when MTA is used than dycal after 3 months and 6 months. Dentin deposition is more in first 3 months than second 3 months for both MTA and dycal.

\section{Discussion}

Dental caries is the most common oral health concern among children. To maintain the arch spaces, integrity, occlusion, and pulp vitality, it is essential to retain primary teeth in the dental arch. Treating deep carious lesion may require the administration of local anesthesia, which proves to be a major challenge to pediatric dentist. A less-conservative and an early intervention of the carious lesion is always a treatment of choice rather than an invasive procedure. Hence, indirect pulp therapy (IPT) performed at early stage is less time consuming, less tedious, and does not involve syringe. It possesses an additional advantage of using the regenerative potential of the tooth, thus having a shift of paradigm from dentin removal to dentin preservation and regeneration.

Various dental materials have been revolutionized for indirect pulp therapy in deciduous teeth, calcium hydroxide being the "Gold Standard" material. Calcium hydroxide was introduced by Hermann in 1921 and is widely used as a pulp capping agent. Studies comparing several agents to calcium hydroxide have been published over the years. ${ }^{16,17}$ Calcium hydroxide has a long tenure of record for clinical success as a pulp capping agent for follow-up of up to 10 years. There are some disadvantages that restrict its use such as poor adhesive quality and improper seal. ${ }^{17}$ Another criticism illustrated of calcium hydroxide was the presence of the so-called "tunnel defects" in reparative dentin formed underneath calcium hydroxide. ${ }^{16}$ The main goal is to achieve reparative dentine formation. Calcium phosphate has good biocompatibility, efficient compressive strength, and superior capacity of producing dentinal bridge than calcium hydroxide.

Glass ionomer also delivers an exceptional bacterial seal and decent biocompatibility when used in close approximation to the pulp.

Newer agents like MTA and biodentin came into limelight lately. MTA was introduced by Torabinajed. MTA induced less pulpal 


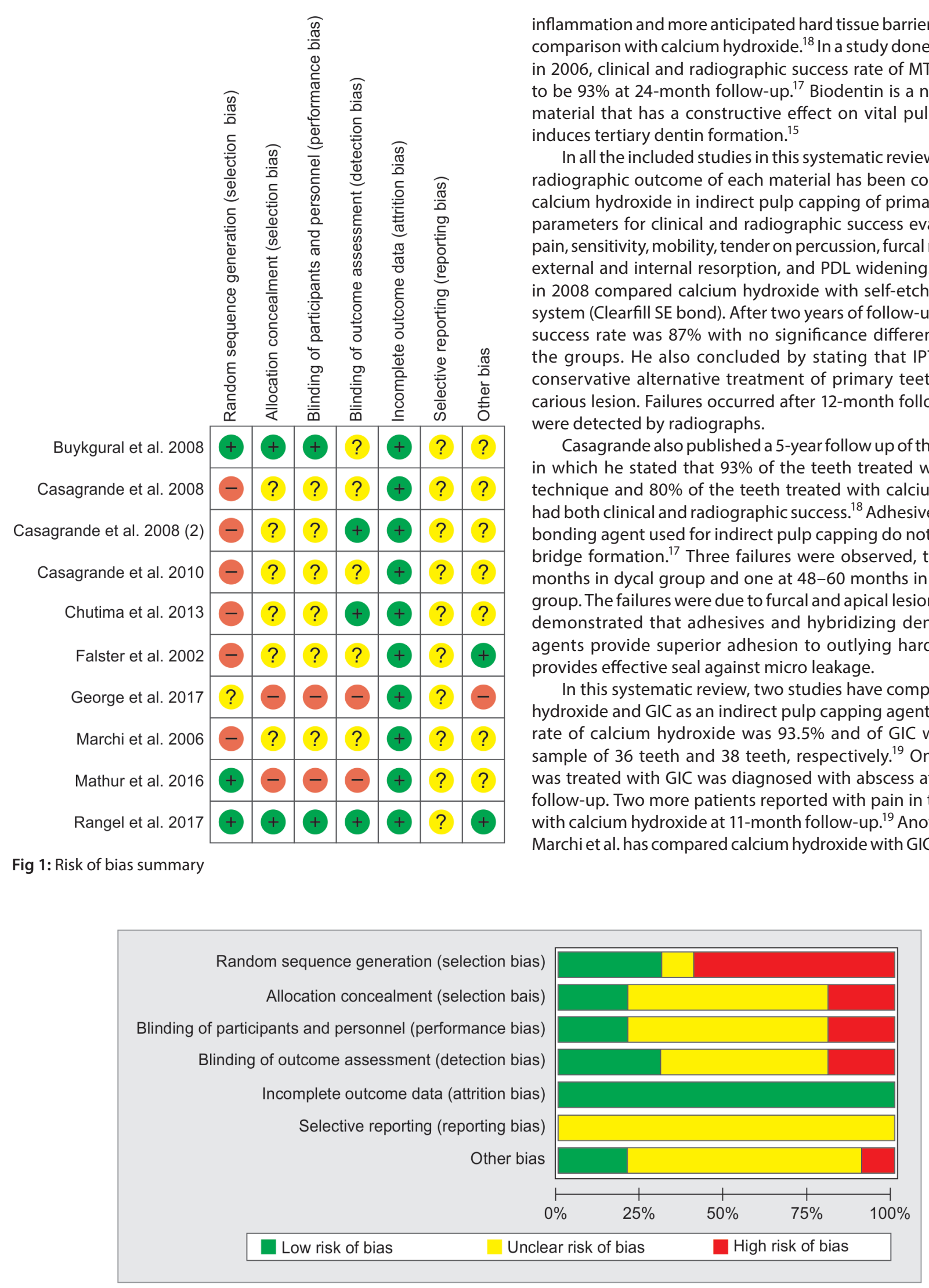

Fig 2: Risk of bias graph 
Table 3: Characteristics of included studies

\begin{tabular}{|c|c|c|c|c|c|c|}
\hline \multirow[b]{2}{*}{ S. no. } & \multirow{2}{*}{$\begin{array}{l}\text { Author and } \\
\text { year }\end{array}$} & \multirow[b]{2}{*}{ Study design } & \multirow[b]{2}{*}{ Sample size } & \multicolumn{2}{|c|}{ Indirect pulp capping agent used } & \multirow[b]{2}{*}{ Outcome assessment } \\
\hline & & & & Test groups & Control & \\
\hline \multirow[t]{4}{*}{1} & $\begin{array}{l}\text { Falster et al., } \\
2002\end{array}$ & $\begin{array}{l}\text { Randomized } \\
\text { controlled trial }\end{array}$ & 48 (3-5 years) & $\begin{array}{l}\text { Adhesive resin } \\
\text { system scotchbond }\end{array}$ & Dycal & $\begin{array}{l}\text { Absence of spontaneous pain and/ } \\
\text { or sensitivity to pressure }\end{array}$ \\
\hline & & & & multipurpose & & $\begin{array}{l}\text { Absence of fistula, edema, and/or } \\
\text { abnormal mobility; }\end{array}$ \\
\hline & & & & & & $\begin{array}{l}\text { Absence of radiolucencies at the } \\
\text { interradicular and/or periapical } \\
\text { regions }\end{array}$ \\
\hline & & & & & & $\begin{array}{l}\text { - Absence of internal or external root } \\
\text { resorption }\end{array}$ \\
\hline \multirow[t]{6}{*}{2} & $\begin{array}{l}\text { Marchi et al., } \\
2006\end{array}$ & $\begin{array}{l}\text { Randomized } \\
\text { clinical trial }\end{array}$ & 17 children & $\begin{array}{l}\text { Glass ionomer } \\
\text { cement }\end{array}$ & $\begin{array}{l}\text { Calcium } \\
\text { hydroxide }\end{array}$ & $\begin{array}{l}\text { - Absence of pathological root } \\
\text { resorption }\end{array}$ \\
\hline & & & $\begin{array}{l}\text { Experimental group-15 } \\
\text { teeth }\end{array}$ & & & - Absence of periapical lesion \\
\hline & & & Control group -12 teeth & & & - Absence of pain and sensitivity \\
\hline & & & Age group: 4-9 years & & & - Absence of mobility \\
\hline & & & & & & - Absence of fistula \\
\hline & & & & & & - Absence of furcal radiolucency \\
\hline \multirow[t]{4}{*}{3} & $\begin{array}{l}\text { Casagrande } \\
\text { et al., } 2008\end{array}$ & $\begin{array}{l}\text { Randomized } \\
\text { controlled trial }\end{array}$ & 48 primary molars & $\begin{array}{l}\text { Adhesive resin } \\
\text { system scotchbond }\end{array}$ & Dycal & $\begin{array}{l}\text { - Absence of spontaneous pain and/ } \\
\text { or sensitivity to pressure }\end{array}$ \\
\hline & & & $3-5$ years old & multipurpose & & $\begin{array}{l}\text { - Absence of fistula, edema, and/or } \\
\text { abnormal mobility }\end{array}$ \\
\hline & & & & & & $\begin{array}{l}\text { Absence of radiolucencies at the } \\
\text { interradicular and/or periapical } \\
\text { regions }\end{array}$ \\
\hline & & & & & & $\begin{array}{l}\text { - Absence of internal or external root } \\
\text { resorption }\end{array}$ \\
\hline \multirow[t]{4}{*}{4} & $\begin{array}{l}\text { Casagrande } \\
\text { et al., } 2008\end{array}$ & Clinical trial & 40 primary teeth & $\begin{array}{l}\text { Self-etching adhe- } \\
\text { sive system }\end{array}$ & Dycal & $\begin{array}{l}\text { Absence of spontaneous pain and/ } \\
\text { or sensitivity to pressure }\end{array}$ \\
\hline & & & $4-8$ years old & & & $\begin{array}{l}\text { - Absence of fistula, edema, and/or } \\
\text { abnormal mobility }\end{array}$ \\
\hline & & & & & & $\begin{array}{l}\text { - Absence of radiolucencies at the } \\
\text { interradicular and/or periapical } \\
\text { regions }\end{array}$ \\
\hline & & & & & & $\begin{array}{l}\text { - Absence of internal or external root } \\
\text { resorption }\end{array}$ \\
\hline \multirow[t]{5}{*}{5} & $\begin{array}{l}\text { Buyukgural } \\
\text { et al., } 2008\end{array}$ & Clinical trial & 240 primary teeth & $\begin{array}{l}\text { Total-etching with } \\
36 \% \text { phosphoric } \\
\text { acid followed by } \\
\text { an acetone-based } \\
\text { adhesive (prime } \\
\text { and bond NT) }\end{array}$ & $\begin{array}{l}\text { Calcium } \\
\text { hydroxide }\end{array}$ & - Remaining dentin thickness \\
\hline & & & $5-10$ years old & $\begin{array}{l}\text { A self-etch } \\
\text { adhesive system } \\
\text { (Xeno III) }\end{array}$ & & $\begin{array}{l}\text { - Absence of clinical symptoms like } \\
\text { spontaneous pain and/or sensitivity } \\
\text { pressure/percussion, fistula and/or } \\
\text { edema, abnormal mobility }\end{array}$ \\
\hline & & & & $\begin{array}{l}\text { An acetone-based } \\
\text { adhesive (prime } \\
\text { and bond NT) } \\
\text { without prior acid } \\
\text { conditioning }\end{array}$ & & $\begin{array}{l}\text { - Absence of radiolucencies at the } \\
\text { interradicular an periapical regions }\end{array}$ \\
\hline & & & & & & $\begin{array}{l}\text { - Absence of internal or external } \\
\text { resorption }\end{array}$ \\
\hline & & & & & & - Marginal quality of restorations \\
\hline
\end{tabular}


Contd...

\begin{tabular}{|c|c|c|c|c|c|c|}
\hline \multirow[b]{2}{*}{ S. no. } & \multirow{2}{*}{$\begin{array}{l}\text { Author and } \\
\text { year }\end{array}$} & \multirow[b]{2}{*}{ Study design } & \multirow[b]{2}{*}{ Sample size } & \multicolumn{2}{|c|}{ Indirect pulp capping agent used } & \multirow[b]{2}{*}{ Outcome assessment } \\
\hline & & & & Test groups & Control & \\
\hline \multirow[t]{4}{*}{6} & \multirow[t]{4}{*}{$\begin{array}{l}\text { Casagrande } \\
\text { et al., } 2010\end{array}$} & \multirow[t]{4}{*}{ Clinical trial } & 40 primary teeth & \multirow[t]{4}{*}{$\begin{array}{l}\text { Self etching adhesive } \\
\text { system }\end{array}$} & \multirow[t]{4}{*}{ Dycal } & $\begin{array}{l}\text { - Absence of spontaneous pain and/ } \\
\text { or sensitivity to pressure }\end{array}$ \\
\hline & & & \multirow[t]{3}{*}{$4-8$ years old } & & & $\begin{array}{l}\text { - Absence of fistula, edema, and/or } \\
\text { abnormal mobility }\end{array}$ \\
\hline & & & & & & $\begin{array}{l}\text { Absence of radiolucencies at the } \\
\text { interradicular and/or periapical } \\
\text { regions }\end{array}$ \\
\hline & & & & & & $\begin{array}{l}\text { - Absence of internal or external root } \\
\text { resorption }\end{array}$ \\
\hline \multirow[t]{3}{*}{7} & \multirow[t]{3}{*}{$\begin{array}{l}\text { Chutima } \\
\text { et al., } 2013\end{array}$} & \multirow[t]{3}{*}{$\begin{array}{l}\text { Single blinded } \\
\text { randomized } \\
\text { controlled trial }\end{array}$} & \multirow[t]{3}{*}{$\begin{array}{l}82 \text { mandibular primary } \\
\text { molars }\end{array}$} & \multirow[t]{3}{*}{ 3Mix-MP } & \multirow[t]{3}{*}{$\begin{array}{l}\text { Calcium } \\
\text { hydroxide }\end{array}$} & $\begin{array}{l}\text { - Absence of fistula, swelling and } \\
\text { mobility } \\
\text { - Absence of pain }\end{array}$ \\
\hline & & & & & & $\begin{array}{l}\text { Intact lamina dura and absence of } \\
\text { furcal radiolucency }\end{array}$ \\
\hline & & & & & & $\begin{array}{l}\text { - Absence of internal/external } \\
\text { resorption }\end{array}$ \\
\hline \multirow[t]{2}{*}{8} & \multirow{2}{*}{$\begin{array}{l}\text { Mathur } \\
\text { et al., } 2016\end{array}$} & \multirow{2}{*}{$\begin{array}{l}\text { Longitudinal } \\
\text { interventional } \\
\text { randomized } \\
\text { control trial }\end{array}$} & 90 teeth & GIC Type VII & \multirow[t]{2}{*}{ Dycal } & \multirow[t]{2}{*}{ - Mean dentin depth } \\
\hline & & & $7-12$ years & MTA & & \\
\hline \multirow[t]{6}{*}{9} & \multirow{6}{*}{$\begin{array}{l}\text { Rangel } \\
\text { et al., } 2017\end{array}$} & \multirow{6}{*}{$\begin{array}{l}\text { Single-blinded } \\
\text { randomized } \\
\text { split-mouth } \\
\text { clinical trial }\end{array}$} & \multirow{6}{*}{$\begin{array}{l}\text { Sample size: } 80 \text { patients } \\
160 \text { teeth }\end{array}$} & \multirow[t]{6}{*}{ Biodentine } & \multirow{6}{*}{$\begin{array}{l}\text { Light } \\
\text { activated } \\
\text { calcium } \\
\text { hydroxide }\end{array}$} & - Radiographic success \\
\hline & & & & & & - Furcal radiolucency \\
\hline & & & & & & - Internal/external root resorption \\
\hline & & & & & & - Periradicular infection \\
\hline & & & & & & - Absence of pain \\
\hline & & & & & & - Absence of sensitivity to percussion \\
\hline \multirow[t]{5}{*}{10} & \multirow{5}{*}{$\begin{array}{l}\text { George } \\
\text { et al., } 2016\end{array}$} & \multirow[t]{5}{*}{ Clinical trial } & Sample size -40 & \multirow[t]{5}{*}{ MTA } & \multirow[t]{5}{*}{ Dycal } & - Radiographic dentin thickness \\
\hline & & & Age group: $5-9$ years & & & - Absence of root resorption \\
\hline & & & & & & - Absence of PDL widening \\
\hline & & & & & & - Absence of periapical radiolucency \\
\hline & & & & & & - Absence of pulpal calcifications \\
\hline
\end{tabular}

rate of $93 \%$ was found in GIC group and $89 \%$ in calcium hydroxide group. The failure rates in both the groups were observation of fistula in 6-12-month follow-up in a sample of 12 teeth and 15 teeth, respectively.

Two more studies have compared calcium hydroxide with MTA in which $100 \%$ success rate was found in MTA group, $93.5 \%$ success rate in calcium hydroxide, and $97 \%$ success rate in GIC group in a sample of 109 teeth. ${ }^{19}$ Another study by George et al. demonstrated that there was a significant difference between MTA and dycal to deposit reparative dentin in a total sample size of 40 . One patient had reported with sinus opening at 6-month follow-up, and no failure rates were seen in the MTA group. ${ }^{20}$

Rangel et al. in 2017 compared biodentin and calcium hydroxide on 160 primary teeth and achieved a combined clinical and radiographic success rates of $98.3 \%$ and $95 \%$, respectively. ${ }^{17}$ In the biodentin group, one tooth was associated with spontaneous pain, mobility, swelling, abscess, furcal radiolucency, and root resorption. In calcium hydroxide group, three teeth were considered failure due to same reasons. All these failures were observed at 6-12-months follow-up. There was no significant difference between the success rates of the two agents after one-year follow-up.
Triple antibiotic paste is used for the management of periapical lesions in RCT of permanent teeth. It can also be used as an indirect pulp capping agent. Chutima in the year 2013 compared calcium hydroxide with 3 Mix-MP and found success rates of $82 \%$ and $81 \%$, respectively, after 11 months and $94 \%$ and $78 \%$, respectively, after 29 months. ${ }^{17}$ Four teeth in the calcium hydroxide group and one tooth in the 3Mix-MP group showed radiographic failures. ${ }^{6}$ Gardner et al. stated that vancomycin, in combination with calcium hydroxide, was more effective than calcium hydroxide used alone and stimulated a more regular reparative dentin bridge. ${ }^{21}$

The risk of bias for all the studies was assessed using Cochrane criteria. Seven parameters were evaluated to assess the risk of bias on individual studies. Eight out of nine included articles have high risk of bias due to unclear risk in allocation concealment, blinding of participants, personnel and outcome assessment, and high risk in random sequence generation. One study has moderate risk of bias as its maximum parameters for quality is at low risk. High risk of random sequence generation was seen in the studies done by Marchi et al. 2006, Casagrande et al. 2008, Casagrande et al., 2008, and Chutima et al., 2013.

Random sequence generation was found to be at low risk in the studies done by Mathur et al., 2016 and Rangel et al., 2017. 
Randomization was not clear in the study done by George et al., 2017. Allocation concealment was not clear in the studies done by Marchi et al., Casagrande et al. and Chutima et al., and was at high risk in the studies done by Mathur et al. and George et al. Allocation concealment was at low risk in the study done by Rangel et al.

There was no clear-cut evidence of blinding of participants and personnel in the studies done by Marchi et al., Casagrande et al. and Chutima et al. Blinding was at high risk in the studies by Mathur et al. and George et al. It was at high risk in the study done by Rangel et al. Blinding of outcome assessment was at low risk in the studies done by Casagrande et al., Chutima et al., and Range et al. Blinding of outcome assessment was not clearly illustrated in the studies by Marchi et al. and Casagrande et al., 2010. High risk of blinding of outcome assessment was seen in the studies by Mathur et al. and George et al. An incomplete outcome of data assessment was seen in all the 9 included studies. Selective reporting of outcome was not clear in all the 9 included studies.

There are certain limitations in the included studies such as: there is a lack of proper random sequence generation and allocation concealment in few studies, and some other studies have small sample size. Few studies have not employed blinding. Therefore, more studies are required with an appropriate randomization technique, allocation concealment and blinding.

\section{Conclusion}

This systematic review aimed to analyze the literature on clinical and radiographic outcome of calcium hydroxide vs other agents in indirect pulp therapy of deciduous teeth. Based on the studies evaluated, there is no clear evidence on the best material for indirect pulp capping agent in primary teeth. Hence, more studies are required in regard to indirect pulp capping of primary teeth.

\section{Clinical Significance}

This systematic review gives detailed information about indirect pulp capping in deciduous teeth using various agents. It is a review of all the articles comparing calcium hydroxide indirect pulp capping and other agents providing the clinician with a clear idea to choose the best indirect pulp capping agent for primary teeth.

\section{References}

1. Ghoddusi J, Forghani M, et al. New approaches in vital pulp therapy in permanent teeth. Iran Endod J 2014;9(1):15.

2. Schröder U. Effects of calcium hydroxide-containing pulp-capping agents on pulp cell migration, proliferation, and differentiation. J Dent Res 1985 Apr;64(4):541-548.
3. Watts $A$, Paterson RC. Cellular responses in the dental pulp: a review. Int Endod J 1981 Jan 1;14(1):10-21.

4. Cox CF, Suzuki S. Re-evaluating pulp protection: calcium hydroxide liners vs. cohesive hybridization. J Am Dent Assoc 1994 Jul 1;125(7):823-831.

5. Hilton TJ. Keys to clinical success with pulp capping: a review of the literature. Oper Dent 2009 Sep;34(5):615-625.

6. Goldberg M, Kulkarni AB, et al. Dentin: Structure, Composition and Mineralization: The role of dentin ECM in dentin formation and mineralization. Front Biosci (Elite Ed) 2011 Apr 26;3:711.

7. Heys DR, Cox CF, et al. Histological considerations of direct pulp capping agents. J Dent Res 1981 Jul;60(7):1371-1379.

8. Cox CF, Sübay RK, et al. Tunnel defects in dentin bridges: their formation following direct pulp capping. Oper Dent 1996;21(1):4-11.

9. Ghoddusi J, Forghani M, et al. New approaches in vital pulp therapy in permanent teeth. Iran Endod J 2014;9(1):15.

10. Bogen G, Kim JS, et al. Direct pulp capping with mineral trioxide aggregate: an observational study. J Am Dent Assoc 2008 Mar 31;139(3):305-315.

11. Laurent $\mathrm{P}$, Camps J, et al. Induction of specific cell resonses to a Ca3 $\mathrm{SiO} 5$-based posterior restorative material. Dent Mater 2008;24(11):1486-1494.

12. Garrocho-Rangel A, Quintana-Guevara K, et al. Bioactive Tricalcium Silicate-based Dentin Substitute as an Indirect Pulp Capping Material for Primary Teeth: A 12-month Follow-up. Pediatr Dent 2017 Sep 15;39(5):377-382.

13. Casagrande L, Bento LW, et al. In vivo outcomes of indirect pulp treatment using a self-etching primer vs calcium hydroxide over the demineralized dentin in primary molars. J Clin Pediatr Dent 2008 Dec 1;33(2):131-136.

14. Casagrande $L$, Westphalen Bento $L$, et al. Indirect pulp treatment in primary teeth: 4-year results. Am J Dent 2010 Feb 1;23(1):34.

15. Trairatvorakul C, Sastararuji T. Indirect pulp treatment vs antibiotic sterilization of deep caries in mandibular primary molars. Int J Paediatr Dent 2014 Jan 1;24(1):23-31.

16. Farsi N, Alamoudi N, et al. Clinical assessment of mineral trioxide aggregate (MTA) as direct pulp capping in young permanent teeth. J Clin Pediatr Dent 2007;31(2):72-76. DOI: 10.17796/ jcpd.31.2.n462281458372u64.

17. Garrocho-Rangel A, Quintana-Guevara K, et al. Bioactive tricalcium silicate-based dentin substitute as an indirect pulp capping material for primary teeth: a 12-month follow-up. Pediatr Dent 2017;39(5): 377-382.

18. Bogen G, Kim JS, et al. Direct pulp capping with mineral trioxide aggregate: an observational study. J Am Dent Assoc 2008 Mar 31;139(3):305-315.

19. Mathur VP, Dhillon JK, et al. Evaluation of indirect pulp capping using three different materials: A randomized control trial using cone-beam computed tomography. Indian J Dent Res 2016 Nov 1;27(6):623.

20. Kitasako $Y$, Ikeda $M$, et al. Pulpal responses to bacterial contamination following dentin bridging beneath hard-setting calcium hydroxide and self-etching adhesive resin system. Dent Traumatol $2008 \mathrm{Apr}$ 1;24(2):201-206.

21. Gardner DE, Mitchell DF, et al. Treatment of pulps of monkeys with vancomycin and calcium hydroxide. J Dent Res 1971 Sep;50(5): 1273-1277. 